\title{
Impacts of Plastic Filming on Growth Environment, Yield Parameters and Quality Attributes of Lettuce
}

\author{
Mohammad SHAH JAHAN ${ }^{1,2 *}$, Md. Dulal SARKAR ${ }^{2}$, \\ Rajesh CHAKRABORTY³ ${ }^{3}$ Abul Hasnat MUHAMMAD SOLAIMAN ${ }^{2}$, \\ Asma AKTER ${ }^{4}$, Sheng SHU ${ }^{1}$, Shirong GUO ${ }^{1 *}$
}

\author{
${ }^{1}$ Nanjing Agricultural University, College of Horticulture, Jiangsu, \\ People’s Republic of China; shahjahansau@gmail.com; shusheng@njau.edu.cn; srguo@njau.edu.cn (*corresponding author) \\ ${ }^{2}$ Sher-e-Bangla Agricultural University, Faculty of Agriculture, Department of Horticulture, Dhaka-1207, \\ Bangladesh;dulalsau_121@yahoo.com; solaimansau@gmail.com \\ ${ }^{3}$ Sher-e-Bangla Agricultural University, Faculty of Agriculture, Department of Agronomy, Dhaka-1207, \\ Bangladesh; rajeshmadhobi9@gmail.com \\ ${ }^{4}$ Sher-e-Bangla Agricultural University, Faculty of Agribusiness Management, Department of Management and Finance, Dhaka- \\ 1207, Bangladesh; asmamfsau@gmail.com
}

\begin{abstract}
The condition of soil and microclimate are prerequisite for proper growth and development of a plant. The environment may be mediated by artificial filming with different colored polyethylene. The mechanism of lettuce growing under colored plastic film remains largely unknown. Thus, to investigate the impact of different plastic film on the growth environment, yield parameters and phytochemical properties of lettuce, the present study was performed. Five different colored polyethylene films viz. black, white, blue, olive and silver were used as a treatment factor, in filed condition. The results demonstrated that the soil $\mathrm{pH}$, temperature and overall performance of lettuce, as well as the phytochemical composition, varied within the use of different films. The maximum soil $\mathrm{pH}$ and temperature were found under black filming plots. Additionally, the black colored plastic film exhibited the best values for most of the yield parameters studied over other plastic films, whereas the field with non-plastic film condition showed the worst data in the experiment. Phytochemical concentrations and nutritive value of lettuce were also significantly affected by the colored plastic treatments. Furthermore, the chlorophyll, anthocyanin, phenols and carotenoids contents were increased in plants grown in soil covered with black polyethylene. Vitamin C content was of 2.5 fold higher in the plants grown in the black film compared to control conditions. The application of plastic film led to elevated concentrations of macro and micronutrients in lettuce because of the direct effect of modified radiation under the plastic film. Taken together, it can be concluded that plastic filming could be used to enhance the yield and nutritional status of lettuce in natural plant production facilities.
\end{abstract}

Keywords: Chlorophyll; lettuce; pH; phytochemicals; polyethylene film; temperature

\section{Introduction}

The conservation of natural resources and their recycled uses are declining day by day on crop production and as a result, the soil and microclimate behaviors have shown dramatic declined. Different plastic films are ubiquitously used in conventional, as well as modern crop production technology systems, for agricultural production, which are conducive to agronomical traits (Bandopadhyay et al., 2018). In that context, filming of crop field and uses of colored plastic film as film material may be the best alternative to conserve the proper moisture and soil temperature (Kader et al., 2017), for crops' growth and development, as well as to suppress weeds' growth (Martin-Closas et al., 2014); therefore, it may enhance the quality production.

The underlying soil temperature and the surface of the film were affected by the color of the material used. Filming is also considered as an agro-technical procedure which can significantly modify microclimate around the plants (Siwek et al., 2007). The film is a natural (straw, sawdust, herbage and other materials) or synthetic (polyethylene in a different color) material, 
which is used for the protection of plant from chilling, drought and other perquisites (Salehi et al., 2013). The color of the film is a big determinant in the microclimate around the plant. Black, silver and white are the color of plastic films predominantly used in vegetable production. Red, brown, blue and other colored films could be potential materials to increase the yield of certain vegetables also. Each of these colors has its own spectral balances which could modify the microclimate of the plants and possibly affect their growth (Franquera and Mabesa, 2016). According to Fatemi et al. (2013), the chlorophyll content of Cucurbita pepo was increased when grown with polyethylene film. Extensive research utilizing certain photo selective film has been reported to increase yields of various horticultural crops (Lamont, 2004). The colored film can affect the spectral balance and quantity of light that affects many plant developmental patterns (Matsoukis et al., 2003; Matsoukis and ChronopoulouSereli, 2003; Matsoukis et al., 2014; Matsoukis et al., 2015). Plants on black plastic film had the highest chlorophyll-a, chlorophyll-b, total chlorophyll contents, maximum number of fruits and highest yield of chili (Ashrafuzzaman et al., 2011).

Lettuce (Lactuca sativa L.) is a leafy vegetable crop used for diverse gastronomic recipes, but also gathered religious and medicinal significance over centuries. Lettuce belongs to the Asteraceae family. Europe and North America originally dominated the market for lettuce, but by the late $20^{\text {th }}$ century the consumption of lettuce had spread throughout the world. Lettuce is the most abundant leafy vegetable consumed in its raw form by humans. The production strategy enhanced the inherent quality of lettuce as well as the yield performance.

As to the authors' knowledge, there is no evidence regarding lettuce growing in filed condition under plastic films, and even more an experiment that study the films' influence over the growth environment, yield and chemical properties of lettuce. From these perspectives, the present study was undertaken, in order to evaluate the performance of the colored plastic film on growth and development of lettuce, to impart a better yield and quality characters.

\section{Materials and Methods}

\section{Plant material and growing conditions}

The experiment was carried out at Sher-e-Bangla Agricultural University, Bangladesh; the area is situated at $23^{\circ} 7 \mathrm{~N}$ latitude and $90^{\circ} 33 \mathrm{E}$ longitude, at an altitude of 8.6 meter above the sea level.

The leafy lettuce variety was used as a test crop. The seedlings of lettuce were raised in plastic shade with recommended methods. Two weeks old seedlings with two true leaves were selected for transplanting in the main field. Five different colored polyethylene films (olive, silver, white, black and blue) were used as film materials for the experiment. Colored poly sheets were $122 \mathrm{~cm}$ wide and $0.9 \mathrm{~mm}$ thick (Mitsubishi Plastics Agri Dream, Tokyo, Japan). Plastic film were placed in all the beds and secured within soil. Holes were made where the seedlings were planted. Plastic films were arranged in a completely randomized block design (RCBD) and at least three biological replications were performed in the experiment. The control sample was not covered at all. The physical and chemical properties of the growing field are shown in Table 1.

\section{Soil temperature and $\mathrm{pH}$ measurement}

Soil temperature measurement started after 7 days of seedlings transplanting to the final harvest of the crop in the main field and $\mathrm{pH}$ was recorded at $10 \mathrm{~cm}$ depth of soil surface according to Sumner (1994).

\section{Morphological data collection}

Number of leaves, leaf length $(\mathrm{cm})$, leaf breadth $(\mathrm{cm})$, leaf fresh weight $(\mathrm{g})$, stem diameter $(\mathrm{cm})$, stem length $(\mathrm{cm})$, root diameter $(\mathrm{cm})$, root length $(\mathrm{cm})$ and yield (t/ha) were measured according to follow the standard procedures.

\section{Chlorophyll content}

The chlorophyll and carotenoid content were extracted according to $\mathrm{Li}$ et al. (2000). Briefly, $0.2 \mathrm{~g}$ fresh leaves were grounded in a mortar with $3 \mathrm{~mL}$ of acetone $(80 \% \mathrm{v} / \mathrm{v})$. Subsequently, $10 \mathrm{~mL}$ of $80 \%$ (v/v) acetone solution was added and the supernatant was extracted until discoloration. The upper phase of the solution was filtered, and absorbance was determined by spectrophotometer.

Chemical analysis

For the evaluation of anthocyanin content, $2 \mathrm{~g}$ fresh leaves were centrifuged with $20 \mathrm{~mL}$ extraction solvent of $\mathrm{HCl}$ and methanol (v/v: $1: 99)$ at $4{ }^{\circ} \mathrm{C}$ for 20 min with $12,000 \mathrm{~g}$. The absorbance of the supernatant was estimated at $530 \mathrm{~nm}$ and $600 \mathrm{~nm}$. The total anthocyanin content was determined as described by Cao et al. (2007). Vitamin C content was estimated by using the indophenol method outlined by Nielsen (2010) with slight modifications. Briefly, $30 \mathrm{~g}$ of fresh leaves were grounded using mortar and pestle with an addition of 10 $\mathrm{mL}$ of trichloroacetic acid (TCA). The mixture was further grounded and strained and the extract was made up to $100 \mathrm{~mL}$ with the TCA mixture. The samples were titrated separately with the indophenol dye solution until a light rose pink persisted for $5 \mathrm{sec}$. The amount of dye used in the titration was determined and used in the calculation of the vitamin $\mathrm{C}$ content.

To obtain a standard curve, $0.05 \mathrm{~g}$ of ascorbic acid was mixed with TCA and titrated as mentioned above. The total phenolic content of leaves was determined by Ragaee et al. (2006) and absorbance was obtained at

Table 1. Physical and chemical properties of the experimental field before experiment

\begin{tabular}{|c|c|c|c|}
\hline Physical properties & Value & Chemical properties & Value \\
\hline Sand $(\%)$ & 39.53 & $\mathrm{pH}$ & 6.20 \\
\hline Silt $(\%)$ & 41.32 & Organic matter $(\%)$ & 0.86 \\
\hline Clay $(\%)$ & 19.15 & Total N (\%) & 0.08 \\
\hline Particle density $\left(\mathrm{g} \mathrm{ccG}^{-1}\right)$ & 2.65 & Available $\mathrm{P}\left(\mu \mathrm{g} \mathrm{g}^{-1}\right)$ & 18.65 \\
\hline Bulk density $\left(\mathrm{g} \mathrm{ccG}^{-1}\right)$ & 1.52 & Available $\mathrm{S}\left(\mu \mathrm{g} \mathrm{g}^{-1}\right)$ & 20.92 \\
\hline \multirow[t]{4}{*}{ Porosity } & 42.56 & Available Fe $\left(\mu \mathrm{g} \mathrm{g}^{-1}\right)$ & 225 \\
\hline & & Available $\mathrm{Zn}\left(\mu \mathrm{g} \mathrm{g}^{-1}\right)$ & 4.55 \\
\hline & & Available $\mathrm{Mg}\left(\mu \mathrm{g} \mathrm{g}^{-1}\right)$ & 0.81 \\
\hline & & Exchangeable K & 0.08 \\
\hline
\end{tabular}


524

$765 \mathrm{~nm}$ by UV-Vis spectrophotometer.

\section{Statistical analysis}

All the data were analyzed by using SPSS 20.0 for Windows (SPSS, Chicago, IL, USA) and are presented as the means \pm SDs. After an analysis of variance (ANOVA), significant differences between means were determined by least significant difference (LSD) test ( $\mathrm{p}$ $<0.05$ ), whereas OriginPro 2016 was used for graphical representations.

\section{Results}

The temperature of the soil under colored plastic film during the plant growth period

Optical properties of different colours of plastic film may change the levels of light radiation reaching the soil, causing increases or decreases in the soil temperature and dissimilarities due to the differences in reflection, absorption and transmission of the solar energy of the coloured plastic films (Schales and Sheldrake, 1963; Tripathi and Katiyar, 1984; Rashidi and Khabbaz, 2011). Through greater heat absorbance, darker colours increase soil temperature, while lighter colours reflect more solar radiation, resulting in lower soil temperature, while increasing the irradiance under the plant canopy.

Generally, the plastic film tends to increase the temperature of the soil, which may generally affect plant growth and development (Streck et al., 1995). The black plastic film exhibited the maximum soil temperature during the entire growing period of lettuce, while the lowest trends were recorded under the control
(Table 2). Same result trend was also found by Ashrafuzzaman et al. (2011). Dark color (black) absorbs solar energy more readily. Similarly, the black plastic film had significantly higher soil temperature than the other plastic film in a study conducted by Rangarajan and Ingall (2001).

\section{pH of soil under plastic film}

The increased soil temperature increased the soil $\mathrm{pH}$ trends (Guoju et al., 2012). The results of the present study shows that colored plastic films significantly increased the soil temperature and, in the context of higher temperature, the $\mathrm{pH}$ of soil also increased. Among the different colored plastic films tested hereby, $\mathrm{pH}$ of the soil (Fig. 1) was higher (8.21) under black colored polyethylene, whereas control showed the lowest $\mathrm{pH}(6.08)$.

\section{Impact of plastic coloured films on lettuce growth} and yield characters

The growth parameters, such as number of leaves, leaf length, leaf breadth, leaf fresh weight, stem diameter, stem length, root diameter and root length have a great impact on yield of a lettuce plant. Compared to non-plastic filming condition, more leaves were produced under black polyethylene, followed by white, blue, silver and olive film (Fig. 2 A).

Under black plastic film, longer leaf and higher leaf breadth grown were noted, which were about 1.3 times more in comparison with plants grown in control condition, that was statistically similar to white and blue plastic films (Figs. 2B-C). In the case of fresh leaves weight per plant, approximately $46 \%$ more weight was

Table 2. Average temperature of the experimental field during the growing period

\begin{tabular}{|c|c|c|c|c|c|c|c|}
\hline & Nov.01 & Nov.15 & Nov.30 & Dec. 15 & Dec.30 & Jan.15 & Jan.30 \\
\hline Control & $26.9^{\circ} \mathrm{C}$ & $25.8^{\circ} \mathrm{C}$ & $23.1^{\circ} \mathrm{C}$ & $18.2^{\circ} \mathrm{C}$ & $18.9^{\circ} \mathrm{C}$ & $21.4^{\circ} \mathrm{C}$ & $20.6^{\circ} \mathrm{C}$ \\
\hline Olive & $28.9^{\circ} \mathrm{C}$ & $27.5^{\circ} \mathrm{C}$ & $24.6^{\circ} \mathrm{C}$ & $20.2^{\circ} \mathrm{C}$ & $21.4^{\circ} \mathrm{C}$ & $23.1^{\circ} \mathrm{C}$ & $22.3^{\circ} \mathrm{C}$ \\
\hline Silver & $28.8^{\circ} \mathrm{C}$ & $27.7^{\circ} \mathrm{C}$ & $24.9^{\circ} \mathrm{C}$ & $19.9^{\circ} \mathrm{C}$ & $21.8^{\circ} \mathrm{C}$ & $23.9^{\circ} \mathrm{C}$ & $22.9^{\circ} \mathrm{C}$ \\
\hline White & $28.6^{\circ} \mathrm{C}$ & $27.6^{\circ} \mathrm{C}$ & $25.1^{\circ} \mathrm{C}$ & $20.8^{\circ} \mathrm{C}$ & $22.3^{\circ} \mathrm{C}$ & $24.3^{\circ} \mathrm{C}$ & $23.6^{\circ} \mathrm{C}$ \\
\hline Black & $29.9^{\circ} \mathrm{C}$ & $28.8^{\circ} \mathrm{C}$ & $26.2^{\circ} \mathrm{C}$ & $22.4^{\circ} \mathrm{C}$ & $24.1^{\circ} \mathrm{C}$ & $25.2^{\circ} \mathrm{C}$ & $25.1^{\circ} \mathrm{C}$ \\
\hline Blue & $28.6^{\circ} \mathrm{C}$ & $27.4^{\circ} \mathrm{C}$ & $24.8^{\circ} \mathrm{C}$ & $20.9^{\circ} \mathrm{C}$ & $22.2^{\circ} \mathrm{C}$ & $23.5^{\circ} \mathrm{C}$ & $23.7^{\circ} \mathrm{C}$ \\
\hline
\end{tabular}

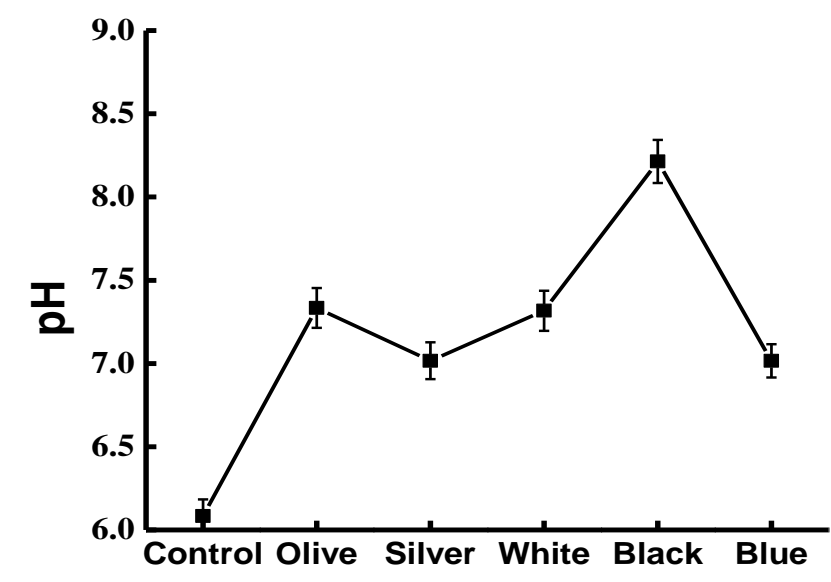

Fig. 1. Effects of different types of plastic films on soil $\mathrm{pH}$. Line graph represents a mean value of three independent experiments and the vertical bars indicate SE $(n=3)$ 
found in black colored polyethylene compared with plants grown under non-plastic filming condition (Fig. $2 \mathrm{H})$.

The widest stem of lettuce was found within plants grown under black plastic, followed by olive colored plastic; that was almost near to $30 \%$ more compared to plants grown under non-plastic filming condition (Fig. $2 \mathrm{E})$. The longest stem was found also within the plants grown under black plastic, followed by olive, silver, white and blue colored plastic, that was proximate to 2.5 fold more longer plants than those grown under control position (Fig. 2D). In respect of root diameter, rough to $23 \%$ more root were produced in black colored plastic mulch (Fig. 2G), compared to control condition. The longest root was found from the plants grown under black plastic, which was statistically similar to blue colored plastic; compared to control, about 2 times bigger root was grown within plants under black polyethylene (Fig. 2F). In respect of total head yield of lettuce statistically significant differences were noticed due to different colored plastic polyethylene. The highest (with approximately $32 \%$ ) total head yield was found from the plants grown under black colored plastic film compared to plants grown under non-plastic film (Fig. 3).

Influence of different plastic films on chlorophyll content in lettuce

Different colored plastic films significantly influenced the chlorophyll content of lettuce (Fig. 4).

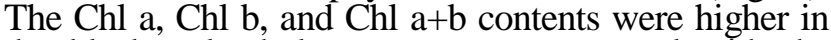
the black polyethylene treatment compared with the white, blue and silver treatments, as well as with control. The chlorophyll concentrations in the black film treatment were as follows: $1.12(\mathrm{Chl}$ a), $0.48(\mathrm{Chl}$ b), $1.60(\mathrm{Chl} \mathrm{a}+\mathrm{b}) \mathrm{mg} \cdot \mathrm{g}^{-1} \mathrm{FW}$. This result indicated that black film strongly affected the photosynthetic system of lettuce. The highest $\mathrm{Chl} \mathrm{a} / \mathrm{b}$ value $(2.61 \mathrm{mg} \mathrm{g}$ ${ }^{1} \mathrm{FW}$ ) was in the blue film treatment and the lowest was in the control treatment.

Effects of plastic films on Vitamin $C$ and total phenolics, anthocyanin and carotenoid content in lettuce

The results indicated that black colored film was significantly effective to increase the vitamin $\mathrm{C}$ content of lettuce. On the contrary, the content of vitamin $\mathrm{C}$ was lower within those plants grown under non-filming conditions (Fig. 5 B). The content of phenolics was also higher in the lettuce grown under black film, compared to other ones (Fig. 5 D).

Vitamin $\mathrm{C}$ and phenolics are considered as the most important elements that are water-soluble antioxidants and the present study indicated that black mulch might be manipulated to enhance plant metabolism and improve the antioxidant properties of lettuce.

The same result was also found by Johkan et al. (2010) and Kim et al. (2011). The results obtained hereby showed that anthocyanin contents were significantly different among the used growing substrates of polyethylene mulch. A considerable amount of anthocyanin contents were recorded from black plastic film, followed by blue, white, silver and olive, while the least amount was measured from non-
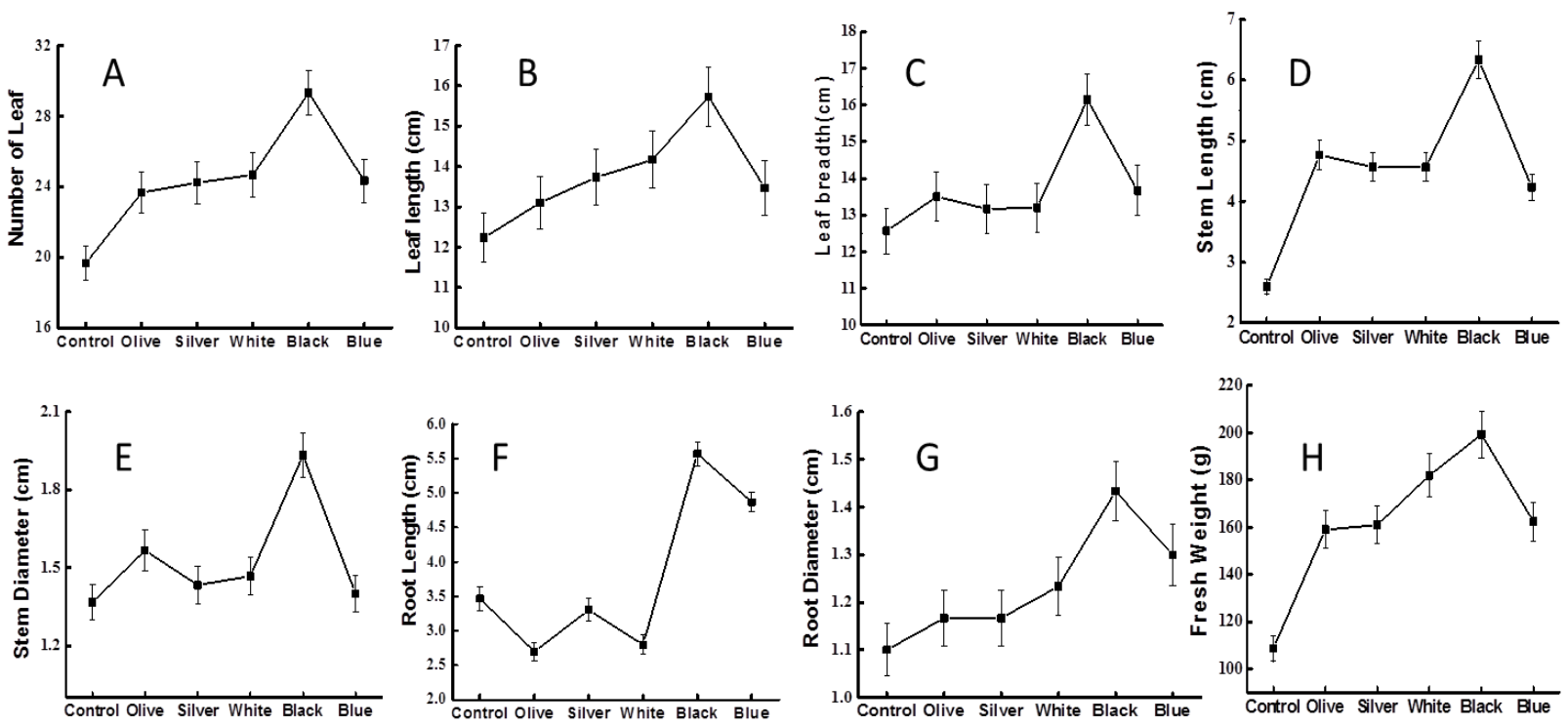

Fig. 2. Effects of different types of plastic films on growth and yield parameters in lettuce. Each line graph represents a mean value of three independent experiments and the vertical bars indicate $\operatorname{SE}(n=3)$ 


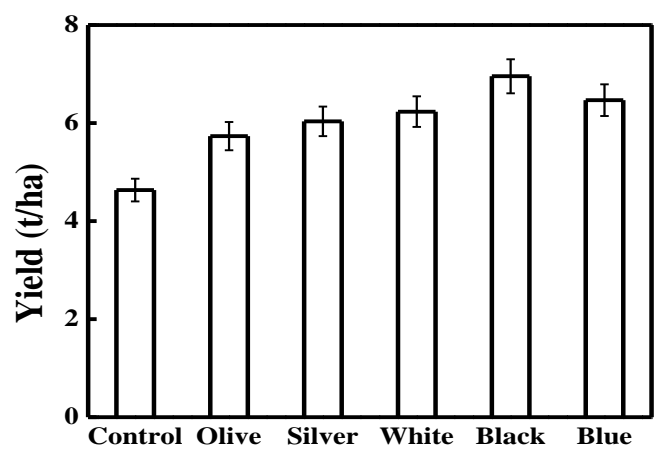

Fig. 3. Effects of different types of plastic films on yield in lettuce. Each histogram represents a mean value of three independent experiments and the vertical bars indicate $\operatorname{SE~}(\mathrm{n}=3)$
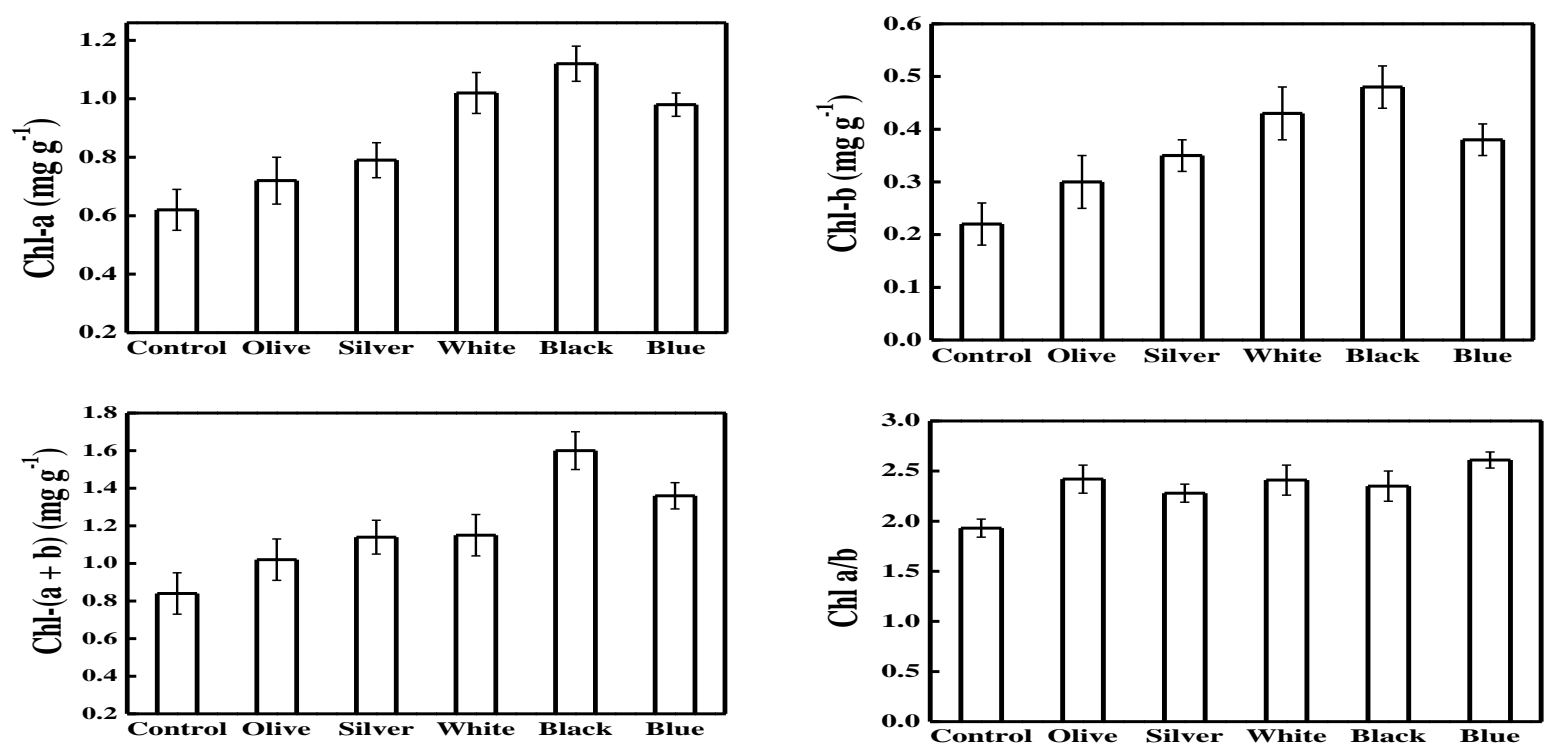

Fig. 4. Effects of different types of plastic films on leaf chlorophyll content in lettuce. Each histogram represents a mean value of three independent experiments and the vertical bars indicate $\mathrm{SE}(\mathrm{n}=3)$
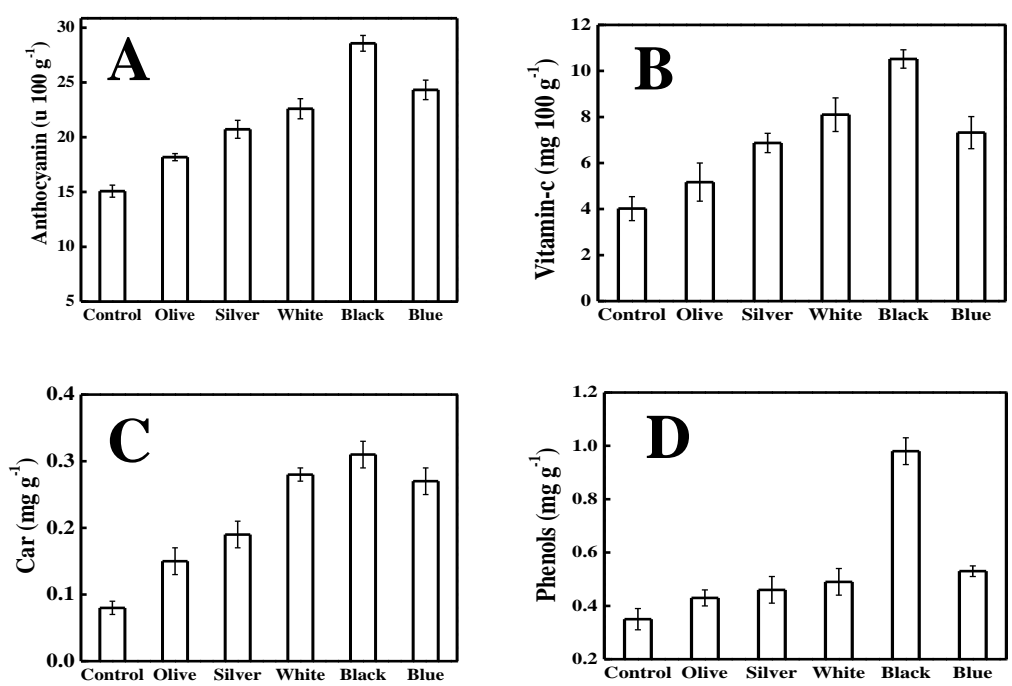

Fig. 5. Effects of different types of plastic films on chemical properties in lettuce. Each histogram represents a mean value of three independent experiments and the vertical bars indicate SE $(n=3)$ 
filming growth condition (Fig. 5 A). The carotenoids content also showed similar trends like chlorophyll contents (Fig. 5 C).

\section{Discussion}

The plant health and photosynthesis processes are greatly influenced by surrounding microclimate conditions whereas some plants must be confrontation of that execrated environmental situations, as well as extreme humidity and temperature (Nassar et al., 2018). Plastic films have passively changed the soil environment through the alteration of soil microclimate and atmosphere (Bandopadhyay et al., 2018). Evaporation and gas exchange components in the soil are decreased, soil temperature is elevated and light transmission becomes lower due to coverage of the soil surface by plastic films (Kasirajan and Ngouajio, 2012). Plastic films reduce the evaporation, which resulted in elevated levels of soil moisture (Qin et al., 2015), thus modifying the physical structure of soil through improving the contents of water aggregates (Siwek et al., 2015). Black and other transparent or translucent mulch films, by adding of pigments may be partially or completely blocking the sunlight and thus sustain a proper growth of plants (Snyder et al., 2015).

Due to the absorbance by black plastic film, which leads to higher temperature into the soil and increases the activity of important enzymes of leaf primordials, thus the number of the leaf of lettuce may increase. The maximum number of leaves per plant was found on the plants filmed with black plastic at all growth stages, followed by the blue plastic film (Ashrafuzzaman et al., 2011). The same trend was also noted by Franquera (2015 a, b), but they reported that when lettuce was grown with red plastic film, it was heavier and had longer leaves compared with lettuce grown with other coloured plastic films.

In the present study, the black colored plastic gave better performance as it retains maximum temperature. Apparently, sufficient soil moisture was conserved under the black plastic film, which might have improved the plant growth. The results of the present study are supported by the findings of Cho et al. (2011). This can be accurate, because black is positioned just before red in the visible light range and it retains the maximum temperature by absorbing the maximum radiance in it.

Siwek et al. (2007) found that the soil temperature raised by plastic filming led to a greater rate of growth and development of leaf. Similarly, the leaf fresh weight was increased under the present study. Ashrafuzzaman et al. (2011) also pointed out that the highest fresh weight of leaf was observed using black plastic, followed by blue and transparent film. Kasperbauer (2010) reported that leaves of basil developed over red film were more succulent and heavier than those grown with black film. Even so, in the present experiment, the weight of fresh leaf was maximum under black film plots. Black filming gave the widest and longest stems of lettuce and it also gave the heavier weight of lettuce heads (Brault, 2001). The temperature under black plastic may increase the activities of stem widening and longing enzymes.

Optimum growth environment like sufficient moisture and temperature maintained when plants were grown under plastic films has a positive impact on plants roots, by triggering the root elongation along with prompted root exudation (Li et al., 2004;
Subrahmaniyan et al., 2006; Wang et al., 2016). Ashrafuzzaman et al.' (2011) reported that the black plastic film produced the highest root volume, followed by the blue plastic film. In contrast, control produced the lowest root volume. The black plastic film may improve the quality of soil and also improve the microclimates of lettuce; as a result, the activities of cell expansion and cell enlargement enzymes have increased, so that the widest and longest roots were found under black filming.

Franquera and Mabesa (2016) pointed out that increasing soil temperature accelerated the rate of plant growth and development and produced significant increase in yield. The modification of the microclimatic conditions of the lettuce plants through the different colored plastic film had some effects on the yield (Siwek et al., 2007). Brault (2001) also reported that black filming of lettuce gave the heavier weight of lettuce head, resulting in the higher head yield of lettuce.

Chlorophyll is one of the most important pigments in higher plants. It is the pigment responsible for capturing light for photosynthesis, which converts light energy into the chemical energy needed for plants' growth. Therefore, chlorophyll is the key player in the interaction with light during the entire life cycle of plants. Photosynthesis can be greatly influenced by the active light properties because of the changes in chlorophyll content and composition (Kobayashi et al., 2013). The color of the film had influenced the concentration of chlorophyll-a in lettuce (Panchal et al., 2001; El-Yazied and Mady, 2012). The differences in the concentration of chlorophyll-a could be due to the spectral distribution of light reflected from the color of the film. In some studies, the red plastic film produced higher concentrations of chlorophyll-a compared with the other colored film (George et al., 2011). But, in the current experiment, it may be seen that black filming performed the best. So, the action of red and black plastic may be the same in this aspect. A similar result also found in Anoectochilus roxburghii (Ye et al., 2017). Light quality and spectral change of solar radiation could affect or change the concentration of chlorophyll-b (Chu et al., 1999). The result of a study in mungbean showed that red led light source can significantly increase the concentrations of chlorophyll (Li et al., 2014). Black plastic has shown a good performance such as red plastic due to its rank, just before red in the visible light range and it absorbed maximum spectral light. The highest value of chlorophyll-a, chlorophyll-b and total chlorophyll was recorded in chili under black plastic film (Ashrafuzzaman et al., 2011). A similar result was also reported by Panchal et al. (2001) who found that film had a significant effect on total chlorophyll contents in chili and the black plastic film was the best for total chlorophyll content among the tested films. CasierraPosada et al. (2011) reported that the total soluble solids (Brix) measured in strawberry fruits showed significant variations among the different colored plastic films. The black film has shown to be the best one on this aspect under the present study.

Different light quality that is influenced by varied plastic film greatly impacts on qualitative traits of lettuce like Vitamin C, carotenoids, phenols, and black polyethylene treatment plants were found to have better values for these traits compared to others plastic filming. Ye et al. (2017) stated that the morphological 
528

traits, antioxidant enzyme activities, photosynthetic pigments content and bioactive compounds content in Anoectochilus roxburghii were different due to the treatment of the different colored plastic film. When plants are grown under $70 \%$ red $+30 \%$ blue LEDs, the amount of chlorophyll and carotenoid contents improved compared to those grown in the glass house condition and the concentration of vitamin $\mathrm{C}$ was 2.25 times more compared to control growth condition (Amoozgar et al., 2017). Jenni et al. (2002) also showed that polyethylene or paper films with at least one black side were effective in controlling weed growth and also they reported that growing lettuce on paper or polyethylene films increased marketable yield. Thus, the above reports are coincided with the present findings.

\section{Conclusions}

It can be summarized that the coloured plastic film has a significant role in lettuce yield production. Among the different colored plastic tested, black polyethylene exhibited the best values for quantitative as well as quality traits under experiment, and thus can be recommended for improving soil properties, increasing lettuce head yield and chemical properties of lettuce as well. Finally, the growers may apply black polyethylene as film material for conserving the soil moisture and improving the microclimate for a better lettuce yield.

\section{References}

Amoozgar A, Mohammadi A, Sabzalian M (2017). Impact of lightemitting diode irradiation on photosynthesis, phytochemical composition and mineral element content of lettuce cv. Grizzly. Photosynthetica 55(1):85-95.

Ashrafuzzaman M, Halim MA, Ismail MR, Shahidullah S, Hossain MA (2011). Effect of plastic mulch on growth and yield of chilli (Capsicum аппиит L.). Brazilian Archives of Biology and Technology 54(2):321-330.

Bandopadhyay S, Martin-Closas L, Pelacho AM, DeBruyn JM (2018). Biodegradable plastic mulch films: Impacts on soil microbial communities and ecosystem functions. Frontiers in Microbiology 9:819.

Brault D (2001). The optical properties of paper and polyethylene mulches and their effect on growth and development of head lettuce (Lactuca Sativa L.), on microclimate modification and weed control in organic soil. McGill University.

Cao J, Jiang W, Zhao Y (2007). Experiment guidance of postharvest physiology and biochemistry of fruits and vegetables. China Light Industry Press, Beijing pp 84-87.

Casierra-Posada F, Fonseca E, Vaughan G (2011). Fruit quality in strawberry (Fragaria sp.) grown on colored plastic mulch. Agronomía Colombiana 29(3):407-413.

Cho Y-C, Lee JT, Park YG, Jeong BR (2011). Effect of mulching material and planting density on growth and bulb development of shallot (Allium cepa var. ascalonicum Backer). Korean Journal of Plant Resources 24(5):507-513.

Chu Z, Tong Z, Feng L, Zhang Q, Wen X, Song S, Zhu X (1999). Effect of different light quality on photosynthetic characteristics of cucumber leaves. Acta Botanica Sinica 41(8):867-870.

El-Yazied AA, Mady M (2012). Plastic mulch color and potassium foliar application affect growth and productivity of strawberry (Fragaria X ananassa Duch). Journal of Applied Sciences Research 8(2):1227-1239.

Fatemi H, Aroiuee H, Azizi M, Nemati H (2013). Influenced of quality of light reflected of colored mulch on Cucurbita pepo var .rada under field condition. International Journal of Agriculture 3(2):374 380.

Franquera EN (2015a). Effect of plastic mulch color on fresh weight of leaf lettuce (Lactuca sativa L.) and soil carbon dioxide. International Journal of Innovative Research and Development 4(9).

Franquera EN (2015b). Leaf morphological characteristics of leaf lettuce (Lactuca sativa L.) as affected by different colored plastic mulch. Current Agriculture Research Journal 3(1):20-25.

Franquera EN, Mabesa RC (2016). Colored plastic mulch effects on the yield of lettuce (Lactuca sativa L.) and soil temperature. Journal of Advanced Agricultural Technologies 3(3):155-159.

George G, Reed ST, Tansel B, Gordon G (2011). Growth profile of Chamaedorea cataractarum (cascade palm) seedlings with different colored plastic mulch. Journal of Agricultural Science 3(3):39-49.

Guoju X, Qiang Z, Jiangtao B, Fengju Z, Chengke L (2012). The relationship between winter temperature rise and soil fertility properties. Air, Soil and Water Research 5:ASWR-S8599.

Jenni S, Brault D, Stewart K (2002). Degradable mulch as an alternative for weed control in lettuce produced on organic soils. In: XXVI International Horticultural Congress: Sustainability of Horticultural Systems in the 21st Century 638, pp 111-118.

Johkan M, Shoji K, Goto F, Hashida SN, Yoshihara T (2010). Blue light-emitting diode light irradiation of seedlings improves seedling quality and growth after transplanting in red leaf lettuce. HortScience 45(12):1809-1814.

Kader M, Senge M, Mojid M, Ito K (2017). Recent advances in mulching materials and methods for modifying soil environment. Soil and Tillage Research 168:155-166.

Kasirajan S, Ngouajio M(2012). Polyethylene and biodegradable mulches for agricultural applications: a review. Agronomy for Sustainable Development 32(2):501-529.

Kasperbauer M (2010). More than meets the eye: New findings on how mulch color can affect food plants. Auburn University, Auburn Alabama, 36849.

Kim BS, Lee HO, Kim JY, Kwon KH, Cha HS, Kim JH (2011). An effect of light emitting diode (LED) irradiation treatment on the amplification of functional components of immature strawberry. Horticulture, Environment, and Biotechnology 52(1):35-39.

Kobayashi K, Amore T, Lazaro M (2013). Light-emitting diodes (LEDs) for miniature hydroponic lettuce. Optics and Photonics Journal 3(1):74-77.

Lamont J (2004). Vegetable production using plasticulture. The Pennsylvania State University University Park, Pennsylvania

Li FM, Lu ZG, Yue M (2014). Analysis of photosynthetic characteristics and UV-B absorbing compounds in mung bean using UV-B and red LED radiation. Journal of Analytical Methods in Chemistry 1-5.

Li FM, Wang J, Xu JZ, Xu HL (2004). Productivity and soil response to plastic film mulching durations for spring wheat on entisols in the semiarid Loess Plateau of China. Soil and Tillage Research 78(1):9-20. 
Li H, Sun Q, Zhao S, Zhang W (2000). Principles and techniques of plant physiological biochemical experiment. Higher Education, Beijing, pp 195-197.

Martin-Closas L, Botet R, Pelacho A (2014). An in vitro crop plant ecotoxicity test for agricultural bioplastic constituents. Polymer Degradation and Stability 108:250-256.

Matsoukis A, Chronopoulou-Sereli A (2003). An investigation of the effects of environmental factors on Lantana camara L. subsp. camara responses to paclobutrazol and mepiquat chloride. The Journal of Horticultural Science and Biotechnology 78(3):381385.

Matsoukis A, Gasparatos D, Chronopoulou-Sereli A (2014). Environmental conditions and drenched-applied paclobutrazol effects on lantana specific leaf area and $\mathrm{N}, \mathrm{P}, \mathrm{K}$, and $\mathrm{Mg}$ content. Chilean Journal of Agricultural Research 74(1):117-122.

Matsoukis A, Gasparatos D, Chronopoulou-Sereli A (2015). Impact of shading and chlormequat chloride on lantana specific leaf area and mineral content. The Journal of Animal and Plant Sciences 25(5):1371-1376

Matsoukis AS, Chronopoulou-Sereli AG, Chronopoulos JK (2003). Growth and flowering of Lantana camara L. subsp. camara as affected by triapenthenol and environmental factors. HortScience 38(2):173-175.

Nassar JM, Khan SM, Diego Rosas Nour V, Almuslem M, Hussain A, , Muhammad M (2018). Compliant plant wearables for localized microclimate and plant growth monitoring. npj Flexible Electronics 2(1):24.

Nielsen SS (2010). Vitamin C determination by indophenol method. In Food analysis laboratory manual. Springer, pp 55-60.

Panchal S, Bhatnagar R, Momin R, Chauhan N (2001). Influence of cultural practices on quality of green and red chilli (Capsicum annum L.) fruit. Indian Journal of Agricultural Biochemistry 14:21-24

Qin W, Hu C, Oenema O (2015). Soil mulching significantly enhances yields and water and nitrogen use efficiencies of maize and wheat: a meta-analysis. Scientific Reports 5:16210.

Ragaee S, Abdel-Aal ESM, Noaman M (2006). Antioxidant activity and nutrient composition of selected cereals for food use. Food Chemistry 98(1):32-38.

Rangarajan A, Ingall B (2001). Mulch color affects radicchio quality and yield. HortScience 36(7):1240-1243.

Rashidi M, Khabbaz BG (2011). Effect of plastic mulch and tillage method on yield and yield components of tomato (Lycopersicon esculentum). In 2011 Society for Engineering in Agriculture Conference: Diverse Challenges, Innovative Solutions. Engineers Australia, pp 542.

Salehi R, Kashi A, Mirjalili SM (2013). Improvement of lettuce growth and yield with spacing, mulching and organic fertilizer. International Journal of Agriculture and Crop Sciences 6(16):1137.
Schales F, Sheldrake R (1963). Mulch effects on soil conditions and tomato plant response. In Proceedings 4th National Agricultural Plastic Congress, pp 78-90.

Siwek P, Kalisz A, Domagala-Swiatkiewicz I (2015). The influence of degradable polymer mulches on soil properties and cucumber yield. Agrochimica 59(2):108-123.

Siwek P, Kalisz A, Wojciechowska R (2007). Effect of mulching with film of different colours made from original and recycled polyethylene on the yield of butterhead lettuce and celery. Folia Horticulturae 19(1):25-35.

Snyder K, Grant A, Murray C, Wolff B (2015). The effects of plastic mulch systems on soil temperature and moisture in central Ontario. HortTechnology 25(2):16-170.

Streck N, Schneider F, Buriol G, Heldwein A (1995). Effect of polyethylene mulches on soil temperature and tomato yield in plastic greenhouse. Scientia Agricola 52(3):587-593.

Subrahmaniyan K, Kalaiselvan P, Balasubramanian T, Zhou W (2006). Crop productivity and soil properties as affected by polyethylene film mulch and land configurations in groundnut (Arachis hypogaea L.) (Einfluss von Polyethylenfilm-Mulch und Feldbeschaffenheit auf Ertrag und Bodeneigenschaften im Erdnussanbau [Arachis hypogaea L.]). Archives of Agronomy and Soil Science 52(1):79-103.

Sumner M (1994). Measurement of soil pH: problems and solutions. Communications in Soil Science and Plant Analysis 25(7-8):859879.

Tripathi R, Katiyar T(1984). Effect of mulches on the thermal regime of soil. Soil and Tillage Research 4(4):381-390.

Wang YP, Li XG, Fu T, Wang L, Turner NC, Siddique KH, Li FM (2016). Multi-site assessment of the effects of plastic-film mulch on the soil organic carbon balance in semiarid areas of China. Agricultural and Forest Meteorology 228:42-51.

Ye S, Shao Q, Xu M, Li S, Wu M, Tan X, Su L (2017). Effects of light quality on morphology, enzyme activities, and bioactive compound contents in Anoectochilus roxburghii. Frontiers in Plant Science 8:857. 